\title{
AI based MPPT Controller for Solar PV System
}

\author{
P. Rajasekeran, G. Ezhilarasan, Shaheen P. C, Sahal C. V, Ganesh. M
}

\begin{abstract}
This article discusses Artificial intelligence based Maximum Power Point Tracking (MPPT) for solar Photo-voltaics based system. MPPT is used to improve the efficiency as well as to raise the output through the photovoltaic system through continuous tracking of MPP. The work demands the use of fuzzy logic control technology; hence the PV-cell is interfaced with a DC step-up converter connected with a dc load. Boost converters convert the output of low voltage DC to output of high voltage $D C$. Following taken through the solar panel are thermal factor like temperature and isolation. The validation of the proposed controller is also discussed.
\end{abstract}

Keywords: Fuzzy Logic Controller, PV-cell, Solar tracking maximum power, step-up converter.

\section{INTRODUCTION}

$\mathrm{W}_{\mathrm{e}}$ e are living in a world where the renewable energy sources are getting higher in demand especially solar and wind energy. MPP operation is required since the Photovoltaic system is less efficient and has more non-linearity in its output characteristics [1-3]. Solar energy is clean and noiseless. The installation cost and low efficiency is a problem for photovoltaic, make it difficult to obtain a easy result. MPPT method is used to obtain high efficiency and output. Thus MPPT is preferred when the maximum power from the solar PV Cell to be extracted converted and delivered to the load just to increase the [4]. In case of a fixed voltage tracking, the observed PV voltage is compared with a reference level and the duty cycle is continuously varied to make the PV module to hover around the maximum power point, that is already predetermined.[5]. The fixed voltage tracking method has a drawback of providing inaccurate values due to the thermal variations.

Now days the MPPT is widely as well as compulsorily adopted method when deriving the power from wind energy systems or solar PV systems just to improve the high level of power condition. From main issue of the MPPT is efficiency in the transfer of power from the PV cell which is related to the quantity of daylight or insolation on the PV panels and the electrical parameters of the system. Because the quantity of daylight varies, the static and dynamic characteristics of the connected load that provides the very best efficiency in power transfer also varies, to optimize the efficiency of the system based on the changes in the load characteristics to maximize the power transfer efficiency. This static characteristics of the load is now known as the maximum power point (MPP) hence MPPT is used to determine this maximum point and operate the solar PV panel around it [6-11].

\section{MATERIALS AND METHODS}

\section{A. DC-DC Boost converter}

DC converter is a switching circuit to connect and transfer electrical energy among the input side and the output side with different DC voltage values. The buck -cum-boost converter is one of the most popular converters when compared to the other type of converters and it operates using switching mode principle. Boost cum Buck converter thus capable of increasing as well as decreasing the DC voltage levels just by varying the time period called duty-cycle shown in fig 1 .

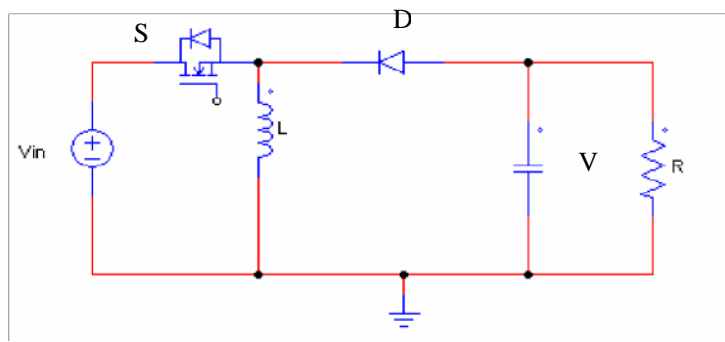

Fig. 1. DC-DC boost converter

\section{B. Fuzzy Controller}

Fuzzy control when used helps in improving of controllers, over the last few years attributable to its simplicity, touch upon inexact inputs, process inaccurate inputs, easy mathematical modelling and might handle nonlinearity. FLC is used to control in order to get the peak operating power of the PV-cell producing with ever-changing atmospheric condition. The working of the fuzzy logic controller is given as in three stages namely the fuzzification stage, rule analysis stage and de-fuzzification stage. The stage is based on the general design of the FLC unit as shown in Fig. 2.

\footnotetext{
Revised Manuscript Received on December 11, 2019.

P.Rajasekeran*, Associate Professor, Department of EEE, Aarupadai Veedu Institute of Technology, Chennai, India.

Dr. G.Ezhilarasan, Professor, Department of EEE, Aarupadai Veedu Institute of Technology, Chennai, India.

Shaheen P. C, Sahal C. V, Ganesh. M, UG, Students, Department of EEE, Aarupadai Veedu Institute of Technology, Chennai, India.
}

Blue Eyes Intelligence Engineering \& Sciences Publication 


\section{RULE}
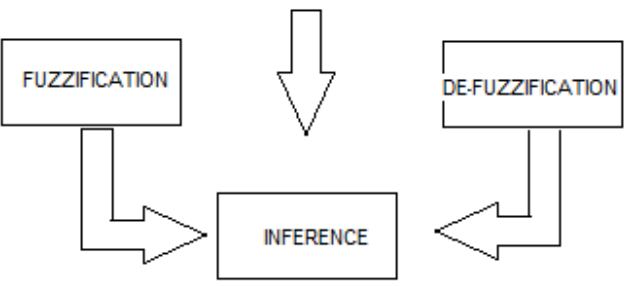

Fig. 2. Fuzzy controller

\section{FUZZY MPPT Controller}

In a fuzzy logic based controller two inputs are fed to have output. Photo voltaic voltage as well as the current is the inputs given and the duty cycle is obtained as the output [12-14]. Duty cycle is nothing but the time period for the ON and OFF. are shown in fig 3 .

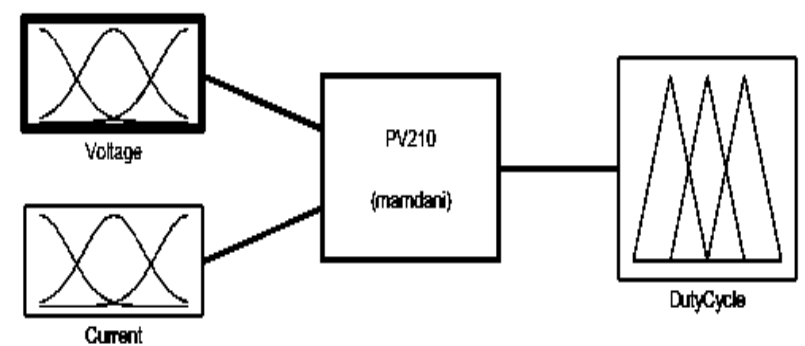

Fig. 3. Fuzzy mppt controller

\section{RESULTS AND DISCUSSION}

The AI based solar system is shown in fig. 4

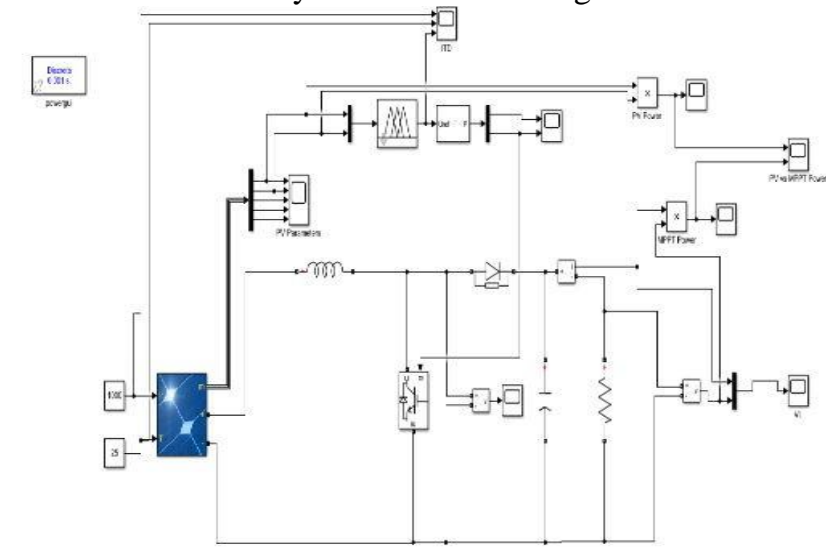

Fig. 4. Model simulation

PV arra (mask) (link)

Implements a PV array bultt of strings of PV modules comnected in paralle. Ead string consists of modules comnected in series.

preset PV indules arailable from NRH System Advisor Model (jan. 2014) as well as user-defined PV module

Inpout $1=$ Sun irradiance, in $w / m 2$, and irput $2=$ Cell temperature, in dog. C.

Parameters Advanced

Array data

Parallel strings 1

Series-connected moduies per string 1

Module data

Module: 15otect 15Ti-215 P

Maximum Power (Wi) 213.15

open circuit woltage voc (V) 36.3

Voliage at maximum power pant Vmp (V) 29

Cells per module (Noell) 60

: Short-tiroult current $\operatorname{Isc}(\mathrm{A}) \quad 7.84$

Ourrent at maximum power point Imp (A) 7.35

Temperature coefficent of $\mathrm{Voc}(\% / \mathrm{deg}, \mathrm{C}) \quad 0.36099$
Fig. 5. Shows the parameters for the PV generation. When the inputs to the fuzzy logic based controller varies PV-Cell power when there is a change of the PV-cell voltage as well as the current with the reference is observed as shown in fig $.6 \mathrm{MLI}$.

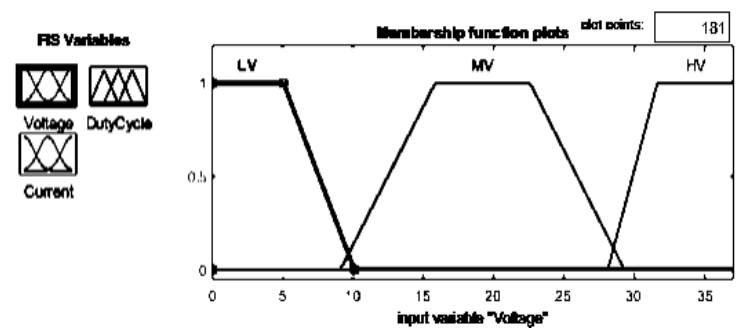

Fig. 6. Input membership function for pv voltage

Thus the photovoltaic voltage, current and the temperature of the PV cell are given as inputs to obtain the duty cycle as output to operate the converter to deliver the peak operating power to the load as shown in fig 7 and the member function output of fuzzy duty cycle is shown in fig. Fig. 8
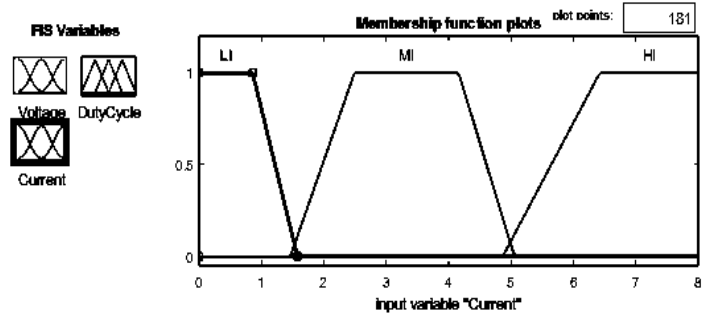

Fig. 7. Input member function of PV current

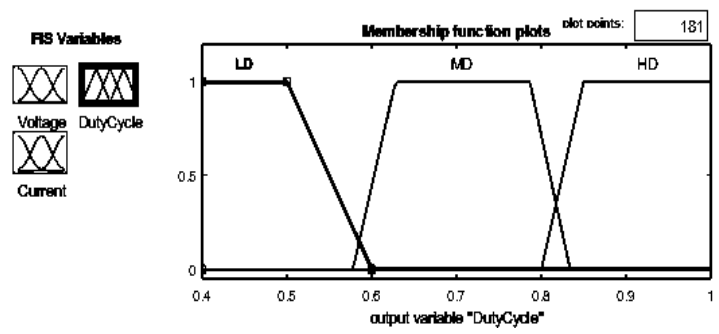

Fig. 8. Output member function of fuzzy duty cycle

The rules dependent upon on the fuzzy logic can be utilized for the fuzzy control system to observe the variation of concluded solar PV system based on input through from efficient use of the converter. Rules of inference are depicted in fig 9. The fig. 10, 11, and fig.12 shows the Irradiance vs temperature vs duty cycle, Voltage -current graph, PV power vs MPPT power graph are respectively.
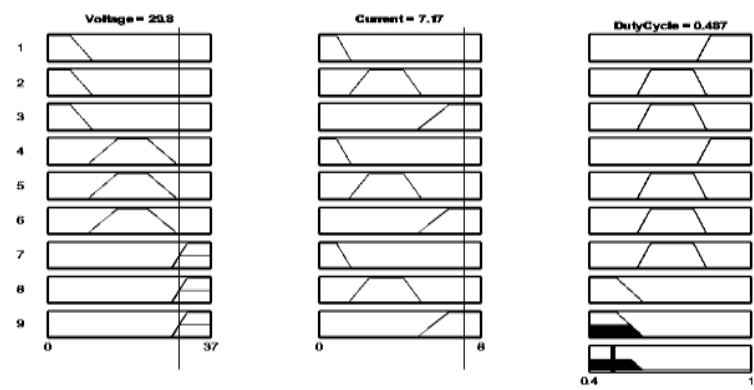

Fig. 9. Fuzzy rules

Fig. 5. PV parameter 


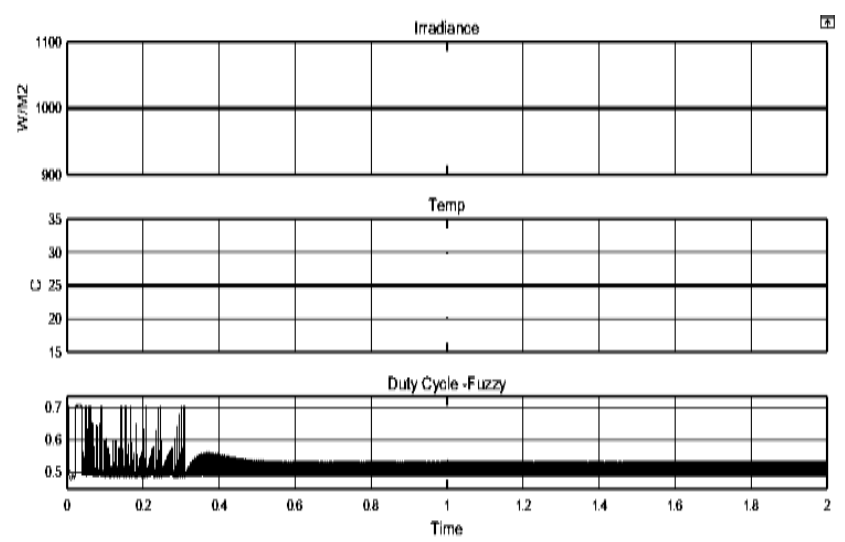

Fig. 10. Irradiance vs temperature vs duty cycle

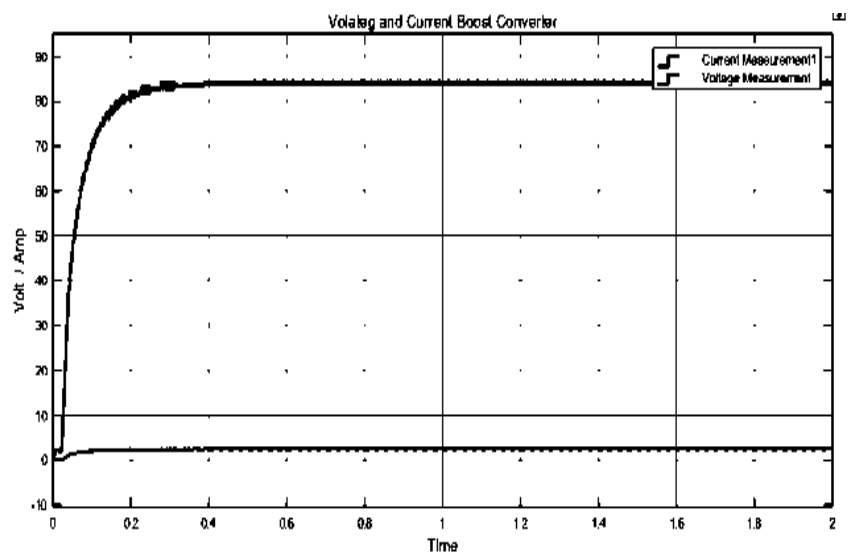

Fig. 11. Voltage -current graph
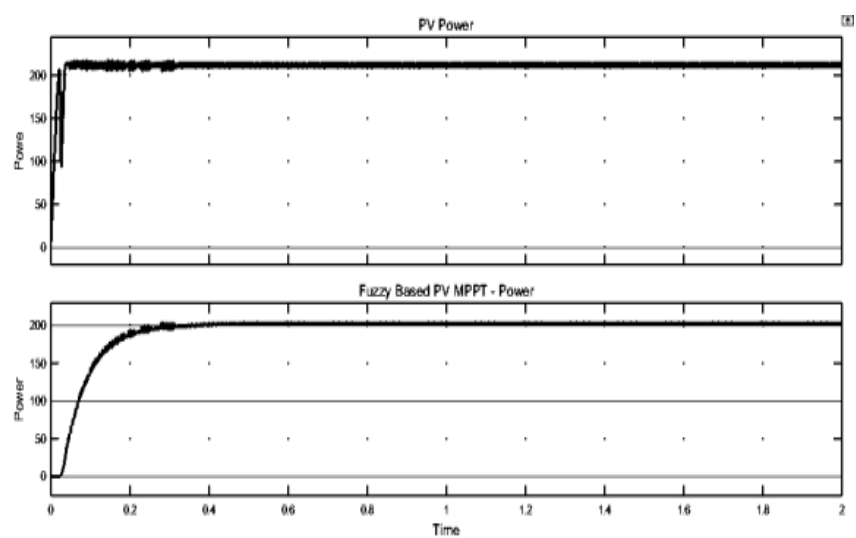

Fig. 12. PV power vs MPPT power graph

The proposed system hardware model is shown in fig. 13 .

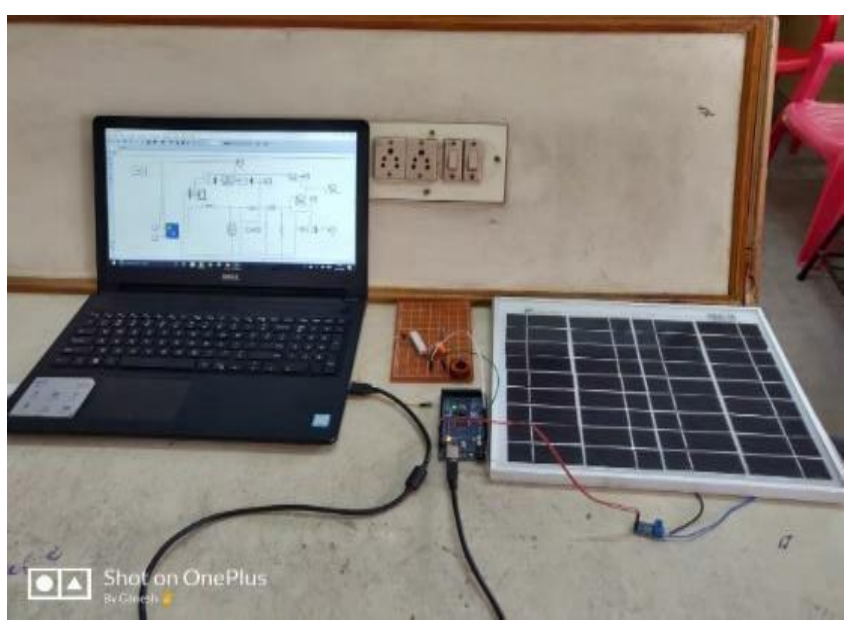

Fig. 13. Hardware model

\section{CONCLUSION}

This paper has been concentrated the modelling of Photovoltaic system and generated maximum power using fuzzy logic based control technology the model is developed through the use of MATLAB/Simulink software with the suitably designed DC buck-cum-boost converter. The tracking of peak point of electrical power from the PV cell also known as MPP was discussed in this article. After the Simulation outcome, the cab will be observed that the method adopted effectively, does the tracking of the operation of power point the solar PV cell under varying ambient condition using fuzzy logic controller. The efficiency and power can be improved through proposed MPPT algorithm.

\section{REFERENCES}

1. Mostefa Kermadi, and E. Madjid Berkouk, "Artificial intelligence-based maximum power point tracking controllers for Photovoltaic systems: Comparative Study, " Science Direct Renewable and Sustainable Energy Reviews, vol. 69, pp 369-386, 2017.

2. N. Vijayalakshmi, "Photovoltaic Fed Multilevel Inverter Design Using PODPWM Technique for Improved Power Quality," International Journal Of Advances In Signal And Image Sciences, vol. 5, no. 1, 2019, pp. 8-14.

3. R. Rajeswari, "Dynamic model and hybrid design of current fed switched inverter for DMPPT fuel cell systems," International journal of advances in signal and image sciences, vol. 1, no. 1, 2015, pp. 29-40.

4. G. Ezhilarasan, and S. S. Dash, "An Improved buck boost converter using auxillary, resonance for photo voltaic based Dynamic voltage Restorer," Springer LNEE series, pp 462-468, 2014.

5. M.J Khan, and L. Mathew, "Maximum Power Point Tracking Control Method for a Hybrid PV/WT/FC Renewable Energy System," Serials publications International Journal of Control Theory and Applications, vol. 10, no. 6, pp. 411-424, 2017.

6. M. J. Khan, and L. Mathew, "Different Kinds of Maximum Power Point Tracking control method for Photovoltaic Systems: A Review," in Achieves of Computational Method, Springer, pp. 1-13, 2016.

7. Rajveer Singh, Shekhawat, Prakash Kanniah, Ezhilarasan Ganesan, and et al, "A comparative study of Hard and Soft switched converters used for solar PV application," Journal of Chemical and Pharmaceutical Sciences, no. 6, pp. 146-150, 2016.

8. E. Ganji, R.K. Moghaddam, A. Toloui, and M. Taghizadeh, "A new control method for leveling output frequency fluctuations in an autonomous PV /FC/UC network with maximum power point tracking of the photovoltaic system," Journal of Intelligent \& Fuzzy Systems, vol. 27, no. 4, pp. 1949-62, 2014.

9. H. Shareef, A. H. Mutlag and A. Mohamed, "A novel approach for fuzzy logic PV inverter controller optimization using lightning search algorithm Neurocomputing," vol.168, pp.435-53. 2015

10. A. M. Mukarram Al-Mohaya, Abd Kadir Mahamad, and Sharifah Saon, "Implementation of Field Programmable Gate Array based Maximum Power Point Tracking controller of photovoltaic system," IEEE 7th International Power Engineering and Optimization Conference, 2013.

11. FarzadSedaghati, Ali Nahavandi, and Mohammad Ali, "PV Maximum Power-Point Tracking by Using Artificial Neural Network," math Problems in Engineering, 2012.

12. http://dx.doi.org/10.1155/2012/506709

13. T. Esram and P. L. Chapman, "Comparison of photovoltaic array maximum power point tracking techniques," IEEE Transactions on Energy Conversion, vol. 22, no. 2, pp. 439-449, 2007.

14. V. B. Manimaran, "Design and Implementation of Solar-Wind Combo For Hybrid Energy Application," International Journal of MC Square Scientific Research, vol.3, no.2, pp.37-42, 2013.

\section{AUTHORS PROFILE}

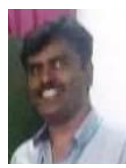

Prof. P. Rajasekaran is currently working in the EEE department of Aarupadai Veedu Institute of Technology. He obtained her B.E in EEE and M.E Degrees in Power Electronics and Drives. He is currently pursuing his Ph.D His areas of interests include power electronics related to the renewable energy. He is

also the vice-principal Administration at AVIT. 
Dr. G. Ezhilarasan is currently working as a professor in EEE department of Aarupadai Veedu Institute of Technology. He obtained his B.E and M.E Degrees from College of Engineering Guindy, and Ph.D from SRM University. His area of interests is in power electronics, drives and renewable energy systems. He is currently a member of ISTE and IET.

Shaeen PC graduated from Aarupadai Veedu Institute of Technology in 2019. He obtained his B.E in EEE and this paper is his final year project work.

Sahal C V graduated from Aarupadai Veedu Institute of Technology in 2019. He obtained his B.E in EEE and this paper is his final year project work.

Ganesh M graduated from Aarupadai Veedu Institute of Technology in 2019. He obtained his B.E in EEE and this paper is his final year project work. 